\title{
射出成形ガラス長繊維強化ポリアミドの衝撃引張特性に及ぼす繊維径の影響
}

\author{
小澤 憲人*1，金 太成吕，角田 大地 ${ }^{* 1}$ ，荒尾 与史彦*3 \\ 谷口 憲彦 ${ }^{* 4}$, 西脇 剛史 ${ }^{* 4}$, 細井 厚志 ${ }^{* 5}$, 川田 宏之*6
}

\section{Influence of fiber diameter on impact tensile properties of injection-molded long glass fiber reinforced polyamide}

\author{
Kento OZAWA $^{* 1}$, Tae Sung KIM ${ }^{* 2}$, Daichi TSUNODA* ${ }^{* 1}$, Yoshihiko ARAO*3, \\ Norihiko TANIGUCHI $^{* 4}$, Tsuyoshi NISHIWAKI ${ }^{* 4}$, Atsushi HOSOI ${ }^{* 5}$ and Hiroyuki KAWADA*6 \\ ${ }^{* 1,{ }^{2} 2}$ Graduate School of Waseda Univ. Dept. of Mechanical Engineering \\ 3-4-1 Okubo, Shinjyuku-ku, Tokyo 169-8555, Japan \\ ${ }^{* 3}$ Tokyo Institute of Technology, Dept. of Chemical Engineering \\ 2-12-1, Ookayama, Meguro-ku, Tokyo 152-8552, Japan \\ ${ }^{*}$ ASICS Corporation, Institute of Sport Science \\ 6-2-1 Takatsukadai, Nishi-ku, Kobe 651-2271, Japan \\ ${ }^{* 5,{ }^{* 6}}$ Waseda Univ. Dept. of Applied Mechanics and Aerospace Engineering \\ 3-4-1 Okubo, Shinjyuku-ku, Tokyo 169-8555, Japan
}

Received 14 December 2015

\begin{abstract}
Applications of fiber reinforced plastics have been expanding due to improvement of not only fuel efficiency but also the motion performance of some recent vehicles. Especially, the demand for injection-molded fiber reinforced thermoplastics is expected to increase because of their superior moldability, productivity and recyclability. In this study, the influence the fiber diameter has on the impact tensile properties of long glass-fiber reinforced polyamide (GF/PA) is investigated using the split Hopkinson pressure bar method. Prior to the tensile tests, an investigation of the fiber-orientation distribution was conducted in order to cut out specimens with the same fiber orientation angle from the injection molded plate. Two types of specimens, referred to as specimens with high- and low orientation angle, were manufactured using glass fibers with average diameters of 13, 17, $23 \mu \mathrm{m}$. In the tensile test, the GF/PA with smallest fiber diameter showed the highest tensile strength and the most significant strain rate dependency on the strength. These effects were more significant for the specimens with high orientation angle. From SEM observations on the fracture surface and an average fiber length measurement, it was observed that the interfacial fracture and the fiber breakage were dominant failure modes under the considered tensile loading conditions. It was suggested that decreasing the stress acting on the fiber/matrix interface by reducing the fiber diameter affected the improvement of the GF/PA strength. Using the modified linear rule of mixtures, the tensile strength was predicted. The predictions showed good agreement with experimental results. Therefore, it is believed that the decrease of critical fiber length is the reason that the impact tensile properties are higher for the samples with smaller fiber diameter.
\end{abstract}

Key words : Composite material, Tensile properties, Impact strength, Strain rate, Fiber diameter, Injection molding

\section{1. 緒言}

近年, 輸送機器の環境性能に対する要求が高まっている，特に自動車は，我が国の輸送機器による $\mathrm{CO}_{2}$ 排出量

No. 15-00657 [DOI: 10.1299/transjsme.15-00657], J-STAGE Advance Publication date : 7 July, 2016

*1 早稲田大学基幹理工学研究科 機械科学専攻（干169-8555 東京都新宿区大久保 3-4-1）

*2 正員, 早稲田大学基幹理工学研究科 機械科学専攻

*3 正員, 東京工業大学理工学研究科 化学工学専攻（广152-8552 東京都目黒区大岡山 2-12-1)

*4 正員，（株）アシックス（干651-2271 兵庫県神戸市西区高塚台 6-2-1）

*5 正員, 早稲田大学基幹理工学部 機械科学・航空学科

*6 正員, フェロー, 早稲田大学基幹理工学部 機械科学・航空学科, 早稲田大学各務記念材料技術研究所

E-mail of corresponding author: kawada@waseda.jp 
の $80 \%$ 以上を占めるなど環境負荷が大きいため，国際的に高い燃費基準が設けられている．そこで，車体重量の 軽減による環境性能・運動性能の向上を目的として, 金属部材を比強度・比剛性に優れる繊維強化プラスチック

(Fiber Reinforced Plastics; FRP) に置換する試みが進められている(Stewart, 2011a)，中でも，量産型自動車におい て, 成形性, 生産性, リサイクル性に優れる繊維強化熱可塑性プラスチックの需要拡大が見込まれている(Hattum and Breugel, 2001, Stewart, 2011b). 特に，熱可塑性プラスチック中に不連続䋊維を分散させた射出成形材は成形サ イクルが $10 \mathrm{~s}$ 程度と生産性が高く, 一体成形による部品点数の削減が可能であるなど自動車部材に適した材料で ある. 射出成形材の適用範囲拡大に際して, 自動車用部材は衝撃に関する安全性が厳しく求められるため, その 衝撃特性の把握が重要となる.

繊維強化熱可塑性プラスチックの射出成形材の機械的性質には, 強化繊維の繊維径, 繊維長(Thomason, 2008), 配向角分布(De Monte et al., 2010)，分散性，界面特性(Arao et al., 2013, Fu et al., 2010，田中他, 2009)など多くの因子 が影響しているが, 中でも FRP の強度の大部分を負担する強化纎維の与える影響は大きいとされている. 射出成 形材の強化繊維として使用されるガラス繊維は，機械的性質や軽量性で炭素緘維に劣るものの，材料コスト削減 の面で利点がある．また，過去の研究においてガラス繊維は衝撃負荷下で引張強度が大幅に向上することが確認 されている(谷口他, 2012, Ochola et al., 2004)。筆者ら(小澤他, 2014)はガラス繊維の形状に着目し，ガラス短繊維強 化ポリアミドの射出成形材の衝撃特性評価を行った，その結果，強化繊維の繊維径が小さいほど，また円形断面 と比較して扁平断面の䋊維を強化材とする供試体ほど，優れた衝撃強度を示すことが明らかとなった。この結果 は，静的負荷下の傾向と一致する(野村他, 2010, Ramsteiner and Theysohn, 1985). 野村ら(野村他, 2010)は, 繊維形 状の変化に伴う強度増加の要因を界面の面積の増加および成形時の流動抵抗の減少に伴う残存䋊維長の増加に見 出した. また, Ramsteiner ら(Ramsteiner and Theysohn, 1985)は, 䋊維径の増加伴う繊維端の高い応力集中によって 樹脂の破壊強度が低下寸ると推察している. 筆者ら(小澤他, 2014)の研究においても, 衝撃負荷下においても界面 の面積比で整理することにより, 強化繊維の細線化, 扁平断面化に伴う引張強度の増加を評価できることを示し ている。しかしながら, 汎用的な短繊維強化熱可塑性プラスチックの成形品中では, 臨界繊維長以下の繊維割合 が多いため，ガラス繊維特有のひずみ速度依存性が十分に反映されていないという課題が考えられる，そこで， 金ら(金他, 2015)は長繊維強化熱可塑性ペレット（Long Fiber Thermoplastics; LFT）を用いた射出成形材について衝 撃引張特性評価を行った. 供試体の平均残存繊維長は短繊維ペレットを使用した場合 ( $400 \mu \mathrm{m}$ 程度) と比較して, $900 \mu \mathrm{m}$ 程度と長く保持された．その結果，ガラス繊維の衝撃強度が十分に反映され，衝撃強度（ひずみ速度 $\approx 100$ $\left.\mathrm{s}^{-1}\right)$ が $50 \%$ 以上増加することが確認された，さらに，強度のひずみ速度依存性が向上することが確認され，LFT の有用性が示された. Thomason(Thomason, 2009)はシャルピー衝撃試験によりガラス長繊維強化ポリアミドの衝 撃特性に及ぼす繊維径の影響を評価し，強化繊維の細線化により衝撃值が向上寸ると報告している．しかし，供 試体間で繊維配向角が統一されていないため, 繊維径が衝撃特性に与える影響を厳密に評価しているとはいえな い. また，負荷速度の変化に伴う機械的性質の変化について十分に検討されているとはいい難い.

本研究ではガラス長繊維強化熱可塑性プラスチックの射出成形材について, 強化繊維の繊維径を考慮した衝撃 引張特性の評価を行うことを目的とした. 繊維配向角調查を行い, 配向角分布を統一した試験片を作製し, 静的， 衝撃試験を行った. 衝撃試験にはホプキンソン棒（Split Hopkinson Pressure Bar; SHPB）試験機を用いることで, 機械的性質およびそのひずみ速度依存性を定量的に評価した．また，炭素繊維を強化材とする長繊維強化熱可塑 性プラスチックと衝撃特性の比較を行った. その後, 繊維長調査, 走查型電子顕微鏡 (Scanning Electron Microscope; SEM）を用いた破断面の観察を行い，破壊メカニズムについて調査した。ささに，不連続繊維強化複合材料の強 度予測式を用いて, 強度予測を行い, 強化繊維の繊維径が衝撃特性に与える影響について考察した。

\section{2. 材料系}

本研究では，LFTペレットを用いて射出成形した板材を供試体とする．LFTペレットは溶融蛣脂中で繊維を引 き抜くことで作製されるため, 通常の短䋊維ペレットと比較して繊維破断を抑制することができ, 残存繊維長を 長く保持できる(Thomason, 2005). 構成基材の諸元を表 1 に示寸. 強化繊維には汎用ガラスである E ガラス (GF), 母材の熱可塑性樹脂にはエンプラの一種であるポリアミド $66(\mathrm{PA})$ を用いる. 使用したガラス緘維ペレットの長 さは $11 \mathrm{~mm}$ である. 本研究では, 強化繊維の繊維径が衝撃特性に与える影響を評価するため, 平均緘維径 $13 \mu \mathrm{m}$, 
$17 \mu \mathrm{m}, 23 \mu \mathrm{m}$ のガラス長繊維を強化材とする䋊維強化ポリアミドの射出成形材について試験を行った. 以降, 各 供試体を強化繊維/繊維径/母材樹脂（GF13/PA，GF17/PA，GF23/PA）で呼称する. 各供試体の繊維径分布は図 1 に 示す通りである，䋊維体積含有率は $39.0 \%$ （58.8 wt\%）とした．また，比較としてポリアミド単体，炭素繊維を 強化材とする長繊維強化ポリアミド (CF/PA) についても試験を行った. 使用した炭素繊維ペレット（ダイセルポ リマー株式会社，プラストロン PA66-CF40-02(L9)-FOOL）の長さは 9 mm，繊維体積含有率は $29.7 \%$ （40 wt\%） である.PA は表 1 に示寸ように吸湿性が非常に高く, 吸湿に伴って機械的特性の低下が生じる場合がある(西田, 加藤, 2011). そのため, 本研究では作製後の全ての試験片について $30^{\circ} \mathrm{C}, 72 \mathrm{~h}$ の条件で真空乾燥を行い, 試験直 前まで真空オーブン内で保存した．また，GF/PA，PAおよびCF/PA は汎用の射出成形機を用いて作製した．成形 条件は表 2 に示寸通りである.

Table 1 Specifications of reinforcement fiber and resin.

\begin{tabular}{c|c|c}
\hline \hline & E-glass & PA \\
\hline Manufacturer & Nittobo & Asahi Kasei \\
\hline Young's modulus $E \mathrm{GPa}$ & 75.0 & 3.00 \\
\hline Strength/Yield stress $\sigma \mathrm{MPa}$ & 3200 & 82 \\
\hline Fracture strain $\mathcal{E}_{\mathrm{f}} \%$ & 4.8 & - \\
\hline Density $\rho \mathrm{g} / \mathrm{cm}^{3}$ & 2.54 & 1.14 \\
\hline Equilibrium moisture uptake $q \%\left(23^{\circ} \mathrm{C}, 50 \% \mathrm{RH}\right)$ & - & 2.5 \\
\hline
\end{tabular}

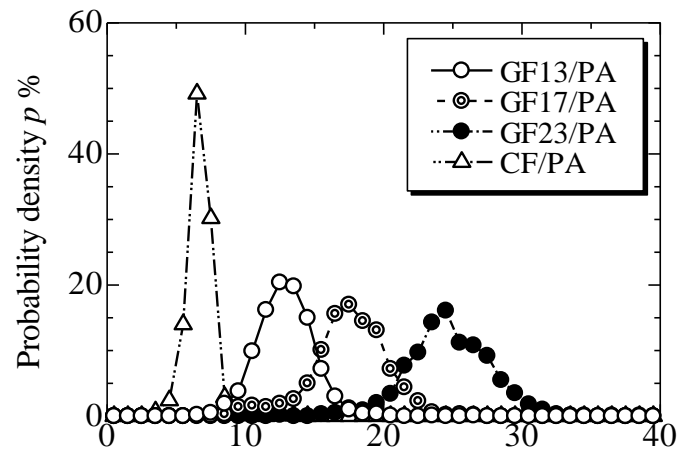

Fiber diameter $d \mu \mathrm{m}$

Fig. 1 Comparison of the fiber diameter distributions of injection molded plate.

Table 2 Injection molding conditions of each specimen.

\begin{tabular}{c|c|c}
\hline \hline & GF/PA, PA & CF/PA \\
\hline Control temperature $T_{\mathrm{c}}{ }^{\circ} \mathrm{C}$ & 285 & 285 \\
\hline Mold temperature $T_{\mathrm{m}}{ }^{\circ} \mathrm{C}$ & 40 & 30 \\
\hline Holding pressure $P_{\mathrm{h}} \mathrm{MPa}$ & 40 & 7.8 \\
\hline Cooling time $t \mathrm{~s}$ & 30 & 20 \\
\hline
\end{tabular}

\section{3. 試験方法}

\section{$3 \cdot 1$ 繊維配向角調查}

射出成形材の機械的特性は強化繊維の配向状態に依存寸る(Bernasconi et al., 2007, De Monte et al., 2010, Zhou and Mallick, 2005). 本研究では, 衝撃特性に及ぼす䋊維径の影響を評価するため, 各繊維径のガラス䋊維を強化材と 寸る試験片おいて強化繊維の配向角分布が統一されていることが望ましい. 強化繊維の配向状態は吐出圧力，金 型温度等の成形条件に加え，母材樹脂の粘度や強化繊維の幾何形状にも影響されるため，同一材料・金型を用い 
て成形を行っても試験片内部の強化繊維の配向状態を容易に制御することはできない，そこで，本研究では射出 成形によって引張試験片を直接成形寸るのではなく, 板厚 $2 \mathrm{~mm}, 96 \times 96 \mathrm{~mm}$ の射出成形板からウォータージェッ ト加工によって図 2 に示すダンベル型試験片を切り出すこととした．射出成形板では金型側面部に近づくほど射 出方向に強化繊維が配向し易いため, 成形板内で配向分布を生じる. したがって, 試験片の切り出し位置を調整 することで，強化繊維の繊維径が異なる供試体の配向角度を統一寸る.

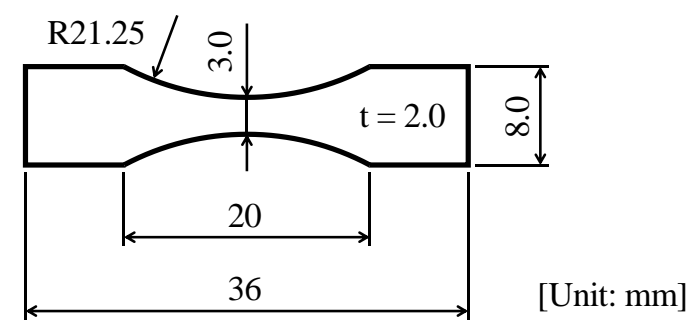

Fig. 2 Geometry of specimen used in tensile test.

配向角調查は図 3 に示寸射出成形板に対して行った. 射出成形板材の中央部を FRP カッターで切断した後, バ フ研磨を施し, デジタルマイクロスコープにて射出方向から断面観察を行った. 配向角分布の観察面は図 3 に示 寸通りである.

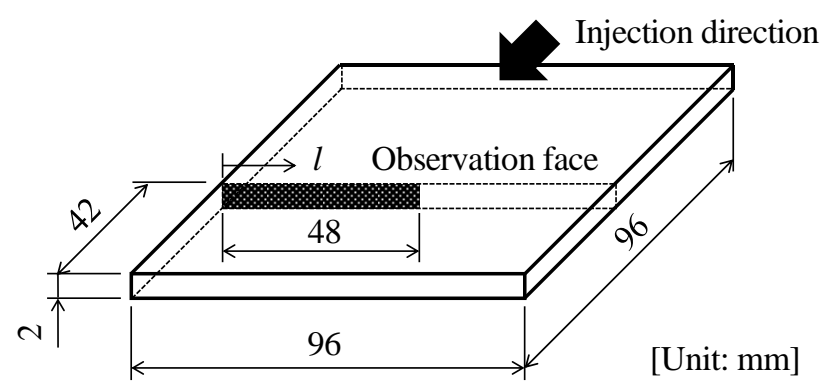

Fig. 3 Geometry of specimen used in fiber orientation investigation.

試験板の端面からの距離 $l=5 \sim 45 \mathrm{~mm}$ の範囲を $5 \mathrm{~mm}$ 間隔で観察し, 得られた試験片断面の画像から各繊維断 面の長短軸比を計測した．測定結果より，式（1）を用いて射出方向，つまり試験片長手方向への強化繊維の配向 角を算出した.

$$
\theta=\cos ^{-1}\left(\frac{d}{D}\right)
$$

ここで, $d$ は各繊維断面の短軸の長さ， $D$ は長軸の長さである.式（1）で得られた值を基にして繊維径の異なる 供試体間で強化繊維の配向角が統一されるよう供試体ごとの切り出し位置を決定した. 配向角調查は各䋊維径の 射出成形板 2 枚, 計 6 枚の板に対して行った.

\section{$3 \cdot 2$ 引張試験}

強化繊維の繊維径がガラス長繊維強化ポリアミドの引張特性に与える影響を評価するため, 静的・衝撃引張試 験を行った．試験片形状は図 2 に示寸通りである. 静的試験は精密万能試験機を用いた．負荷速度は $0.5 \mathrm{~mm} / \mathrm{min}$ とし, 各供試体 5 本以上試験を行った。衝撃試験は, 図 4 に示す引張型 SHPB 試験機を用いた(Naik et al., 2010, Taniguchi et al., 2009, 横山他, 2009). 図 4 の試験機は，本研究で試験片を適切に破断させるために必要な出力を考 慮して設計, 作製した。同試験機はストライカー, 入力棒, 出力棒より構成される. ストライカーを入力棒端部 に設けたヨーク部に衝突させ，励起された応力波を入力棒に貼り付けた箔ひずみゲージおよび出力棒に貼り付け 
た半導体ゲージによりサンプリング $1.0 \mathrm{MHz}$ で測定した。広範囲のひずみ速度域での測定を行うことを目的とし て，ストライカーは $500 \mathrm{~mm}, 800 \mathrm{~mm}$ の 2 種類の長さを用いた．試験片固定部は，図 5 に示すように応力棒先端 の溝に試験片をはめ込むタイプとした．これにより，試験片の強勒な固定が可能となった．また，静的試験にお いても同様な治具を用いて試験片を固定することにより，負荷方式を統一した．SHPB 試験において，試験片の 応力 $\sigma(t)$ は一次元弾性波理論に基づき，次のように表せる.

$$
\sigma=E \frac{A}{A_{\mathrm{S}}} \varepsilon_{\mathrm{T}}(t)
$$

ここで， $\varepsilon_{\mathrm{T}}(t)$ は透過波ひずみ， $A$ は入出力棒の断面積， $E$ は入出力棒の縦弾性率， $A_{\mathrm{s}}$ は試験片断面積である．な お，式 (2) の成立に必要な入出力棒での応力のつり合い(谷口他, 2009)は測定結果より確認している. また，試験 片のひずみ $\varepsilon_{\mathrm{S}}(t)$, ひずみ速度 $\dot{\varepsilon}_{\mathrm{S}}(t)$ は試験片に貼り付けた管ひずみゲージの測定結果より算出した.

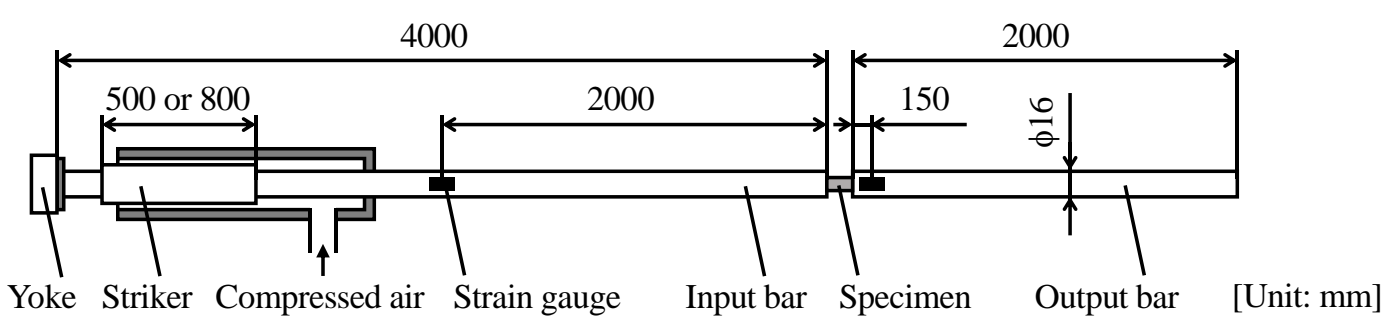

Fig. 4 Tensile type split Hopkinson pressure bar apparatus used in this study.

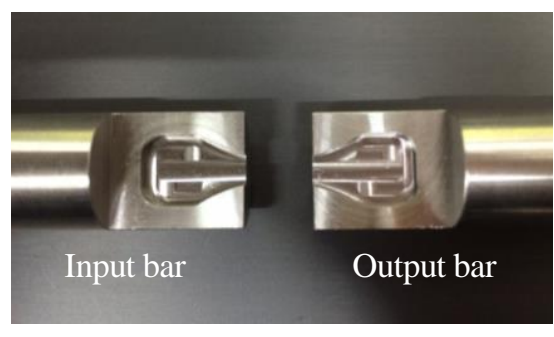

(a) Detail view around chuck

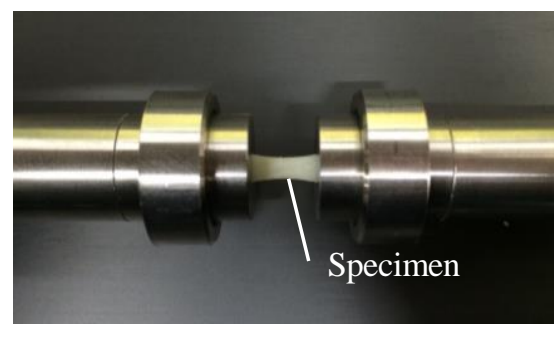

(b) Mounted specimen

Fig. 5 Photographs of tensile type split Hopkinson pressure bar chuck.

\section{$3 \cdot 3$ 繊維長調查}

繊維径の異なる供試体間での䋊維長の違い，引張試験前後での繊維長の変化を把握することを目的として，繊 維長調查を行った. まず, 試験片中央部 $11 \mathrm{~mm}$ をファインカッターにより切り出した. 次に, マッフル炉を用い て $500^{\circ} \mathrm{C}, 1 \mathrm{~h}$ 加熱し母材樹脂を熱分解した. 残余の繊維をデジタルマイクロスコープにより撮影し, 画像処理ソ フトを用いて 2000 本の繊維の長さを測定し，䋊維長分布を取得した.

\section{$3 \cdot 4$ 破断面観察}

各試験片の破壊メカニズムを調査するため，引張試験後の試験片の破断面観察を行った．SEMを用いて荷重負 荷方向から破断面を観察することで，マイクロスケールで破壊形態を評価した。

\section{4. 試験結果}

\section{$4 \cdot 1$ 織維配向角調查結果}

繊維配向角調査の結果を基に決定した試験片の切り出し位置を図 6, 表 3 に示す. 各繊維径について, 1 枚の板 から配向角の異なる 2 種類の試験片（Specimens with High Orientation Angle; HOA specimens, Specimens with Low 
Orientation Angle; LOA specimens）を各 2 本，計 4 本切り出すこととした．決定した切り出し位置での試験片の繊 維配向角分布を図 7 に, HOA specimens および LOA specimens の試験片断面の様子を図 8, 図 9 に示す. 図 7 よ り，試験片の繊維配向角分布はほぼ等しくなっていることが確認できる．なお，同一条件で成形した板の繊維配 向角分布はほぼ同一であることを確認している，図 8, 図 9 より，いずれの試験片も繊維は凝集することなく均 一に分散している．また，図 9 より，LOA specimens では絾維がシェル層とコア層に分かれており，コア層にお いて配向度が低くなっていることが読み取れる，さらに，繊維径の異なる HOA specimens，LOA specimens 同士で 配向度が同様であることも読み取れる，これより，引張試験において繊維径の異なる供試体を比較する際，繊維 配向角の影響は除外できると考えられる.

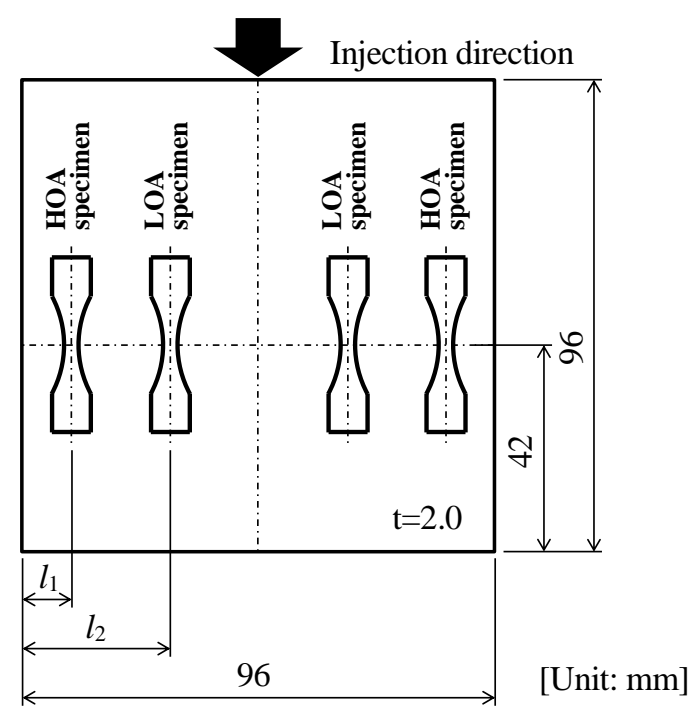

Fig. 6 Cutting position of injection molded plate. Two types of specimens, referred to as specimens with high- and low orientation angle (HOA specimens and LOA specimens), are manufactured using glass fiber with average diameters of $13,17,23 \mu \mathrm{m}$ and carbon fiber with average diameter of $7 \mu \mathrm{m}$.

Table 3 Cutting position of tensile test specimens.

\begin{tabular}{c|c|c|c|c}
\hline \hline & GF13/PA & GF17/PA & GF23/PA & CF/PA \\
\hline Cutting position for HOA specimens $l_{1} \mathrm{~mm}$ & 10 & 10 & 15 & 7 \\
\hline Cutting position for LOA specimens $l_{2} \mathrm{~mm}$ & 30 & 30 & 30 & 20 \\
\hline
\end{tabular}

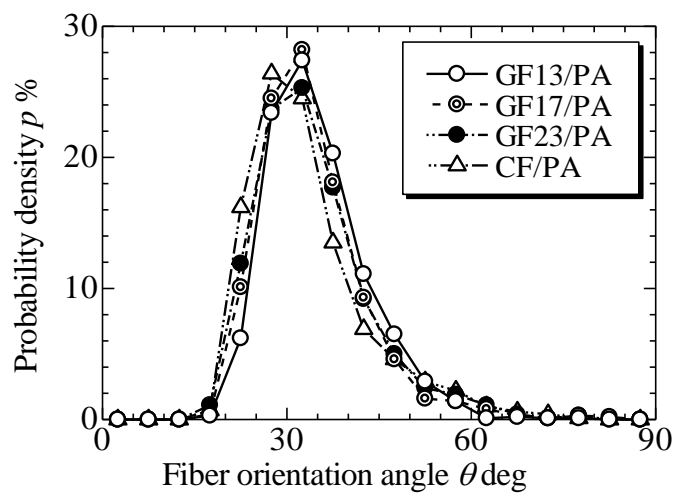

(a) HOA specimens

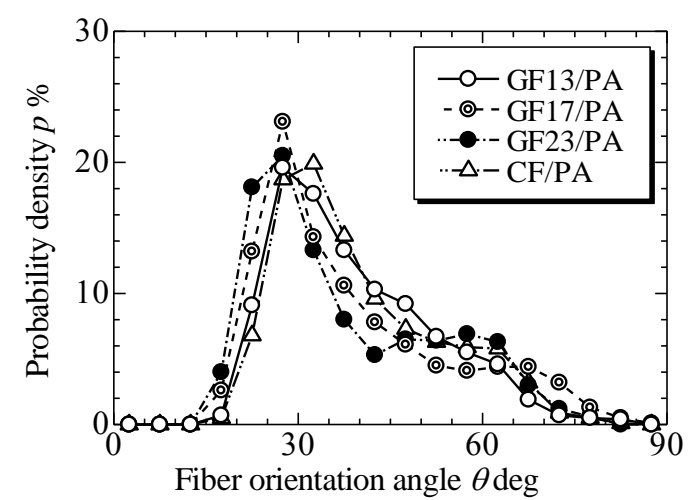

(b) LOA specimens

Fig. 7 Comparison of the fiber orientation distributions of specimens with high- and low orientation angle (HOA specimens and LOA specimens). The specimens have the same fiber orientation angle. 
Ozawa, Kim, Tsunoda, Arao, Taniguchi, Nishiwaki, Hosoi and Kawada,

Transactions of the JSME (in Japanese), Vol.82, No.839 (2016)

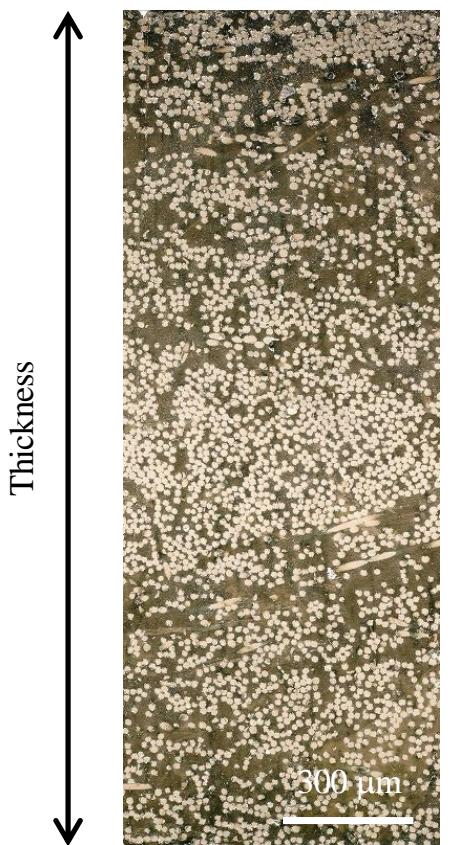

(a) GF13/PA $\left(l_{1}=10 \mathrm{~mm}\right)$

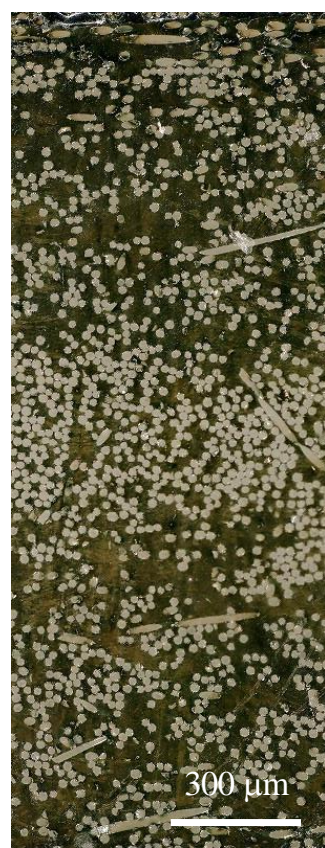

(b) GF17/PA $\left(l_{1}=10 \mathrm{~mm}\right)$

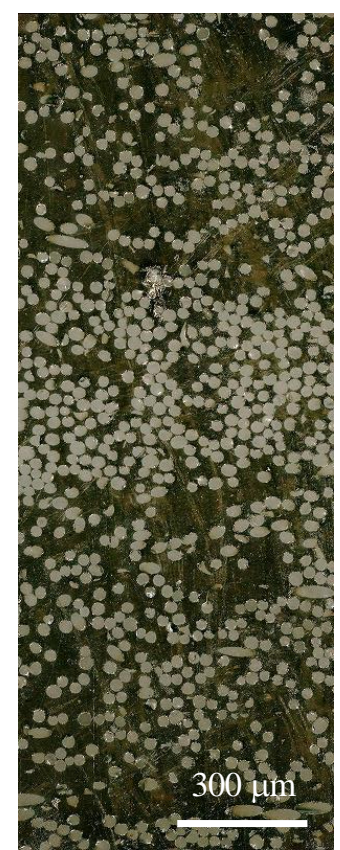

(c) GF23/PA $\left(l_{1}=15 \mathrm{~mm}\right)$

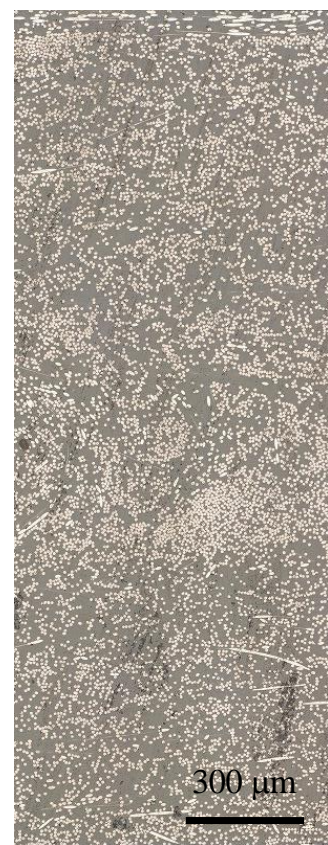

(d) $\mathrm{CF} / \mathrm{PA}\left(l_{1}=7 \mathrm{~mm}\right)$

Fig. 8 Comparison of cross sectional areas of specimens observed using digital microscope (HOA specimens).

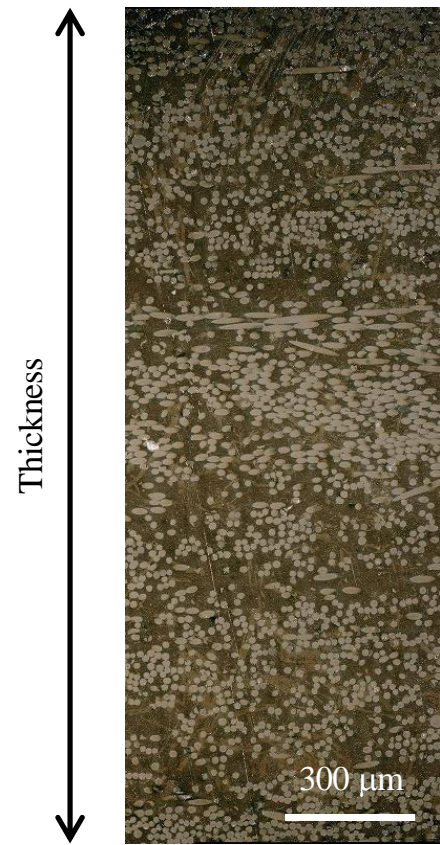

(a) $\mathrm{GF} 13 / \mathrm{PA}\left(l_{2}=30 \mathrm{~mm}\right)$

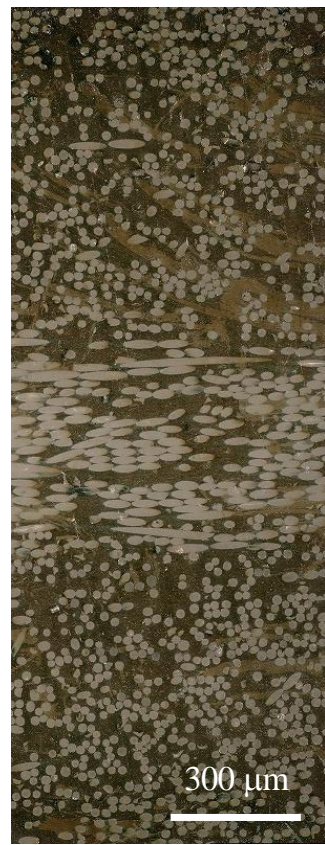

(b) GF17/PA ( $\left.l_{2}=30 \mathrm{~mm}\right)$

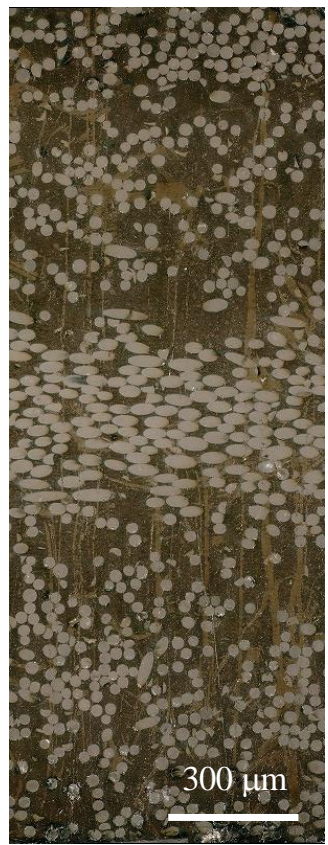

(c) GF23/PA $\left(l_{2}=30 \mathrm{~mm}\right)$

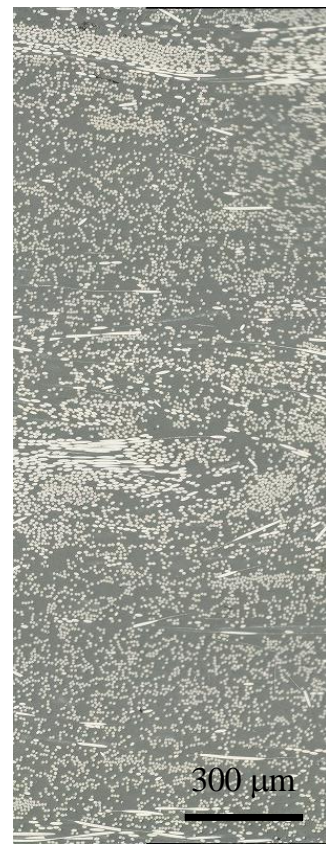

(d) $\mathrm{CF} / \mathrm{PA}\left(l_{2}=20 \mathrm{~mm}\right)$

Fig. 9 Comparison of cross sectional areas of specimens observed using digital microscope (LOA specimens). 


\section{4-2 引張試験結果}

静的，衝撃試験の結果得られた GF/PA，CF/PA，PA の代表的な応力ーひずみ線図を図 10 に，引張強度とひず み速度の関係を傾向線と共に図 11 に示す. 衝撃試験の結果は, 試験により発生する応力波の第一波で試験片が破 断した結果のみ示している。CF/PA については繊維体積含有率が GF/PA と統一されていないため，CF/PA

$\left(V_{\mathrm{f}}=29.7 \%\right)$ と $\mathrm{PA} の$ 静的引張試験結果を基に複合則を用いて算出した換算值 $\mathrm{CF} / \mathrm{PA} （ V_{\mathrm{f}}=39.0 \%$ equivalent $)$ を併 記した.

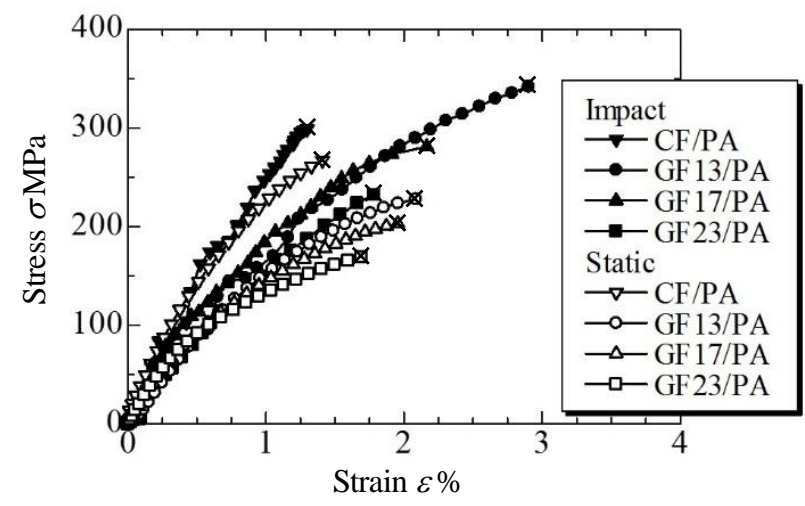

(a) HOA specimens

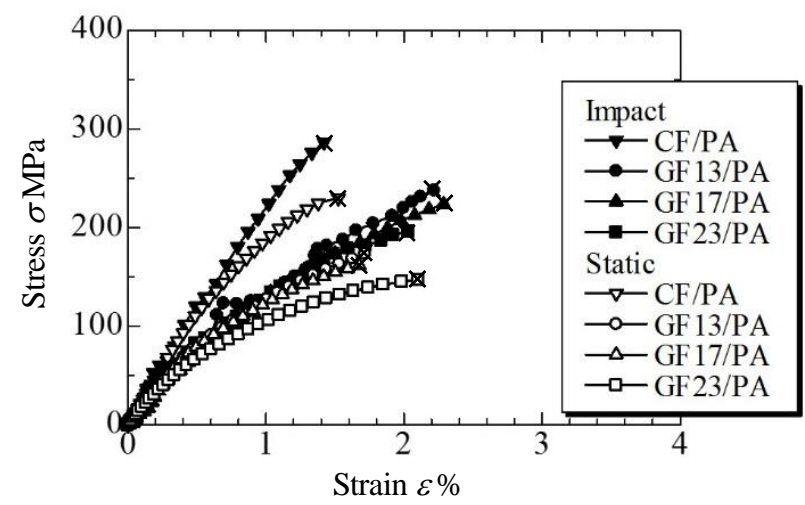

(b) LOA specimens

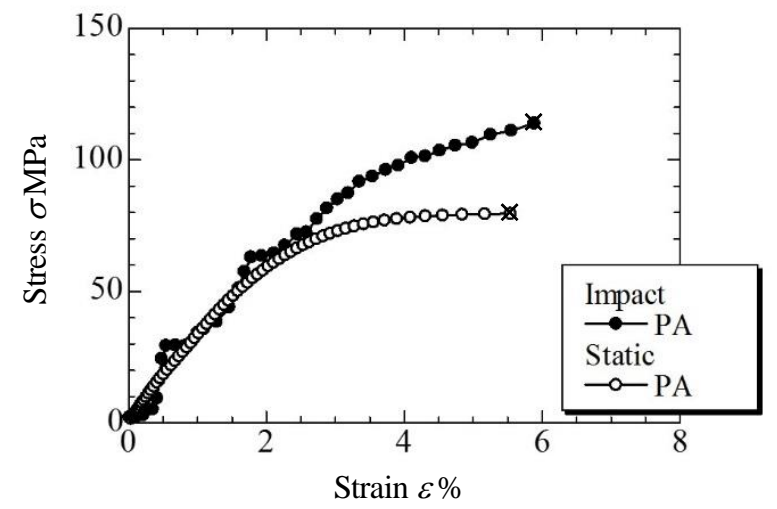

(c) PA

Fig. 10 Comparison of stress-strain curves of specimens with high- and low orientation angle (HOA specimens and LOA specimens) and PA under static and impact loading.

図 10, 図 11 より，GF/PA，CF/PA ともに，ひずみ速度の増加に伴って強度が増加することが確認できる。強度 の増加挙動はひずみ速度の増加に伴い, 緩やかになっている. GF/PA の強度増加挙動は, ガラス繊維の挙動(谷口 他, 2012) と類似しており，強化繊維の特性が FRP 全体の特性に発現していることが分かる．また，GF/PAにおい 
ては，ガラス䋊維径が小さな試験片ほじ高い強度を示していることも確認できる．纎維配向角に関して，HOA specimens は LOA specimens と比較してより高い強度を示している. これは, 繊維配向度の高い試験片において強 化繊維の強度がより顕著に発現したためだと考えられる。

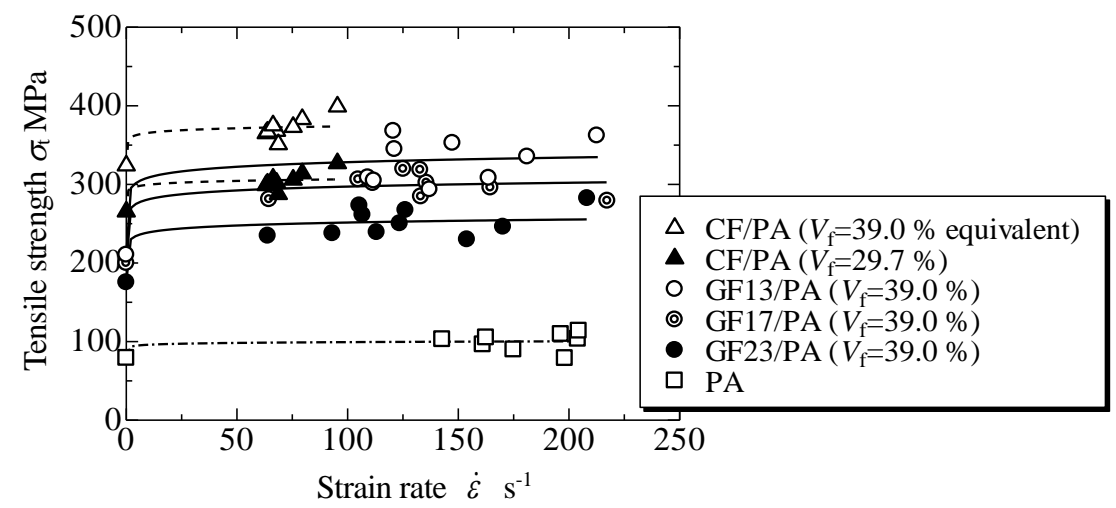

(a) HOA specimens and PA

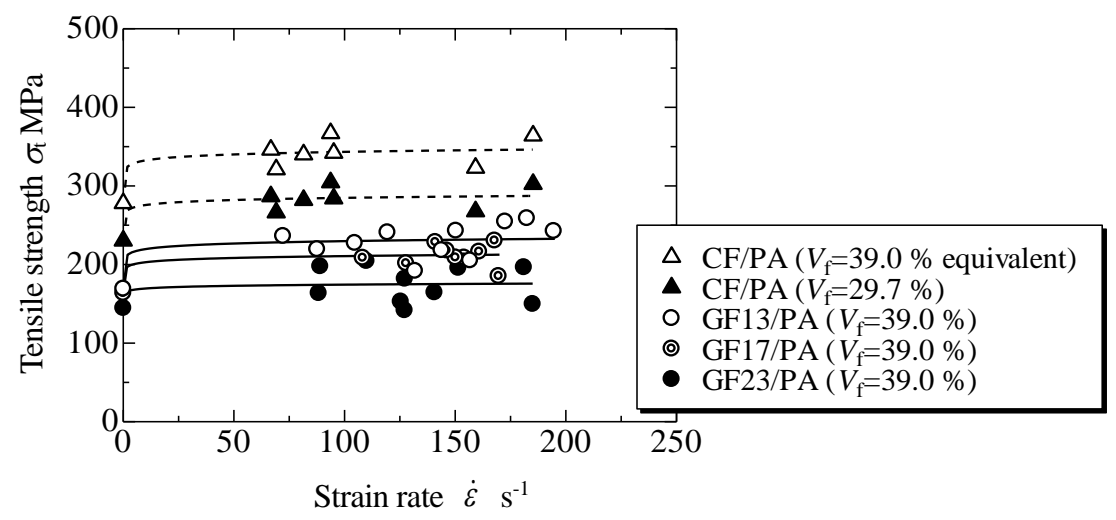

(b) LOA specimens

Fig. 11 Comparison of strain rate dependency of tensile strength. The GF/PA with smaller fiber diameter shows higher tensile strength at any strain rate. In comparison to the LOA specimens, the HOA specimens show the most significant increment of the strength.

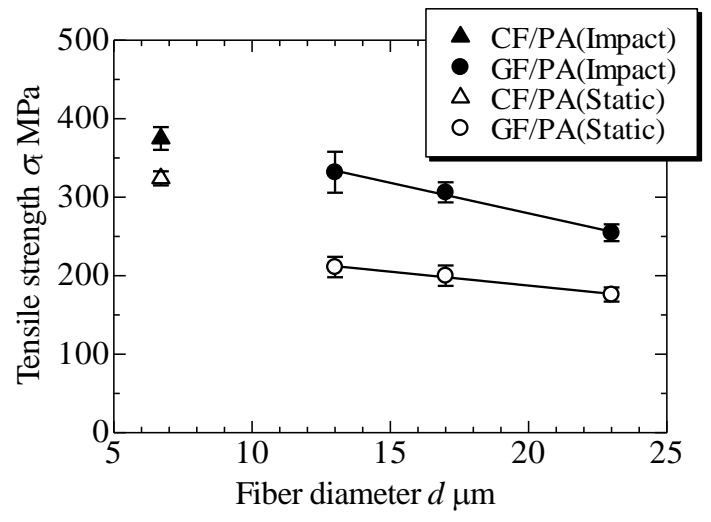

(a) HOA specimens

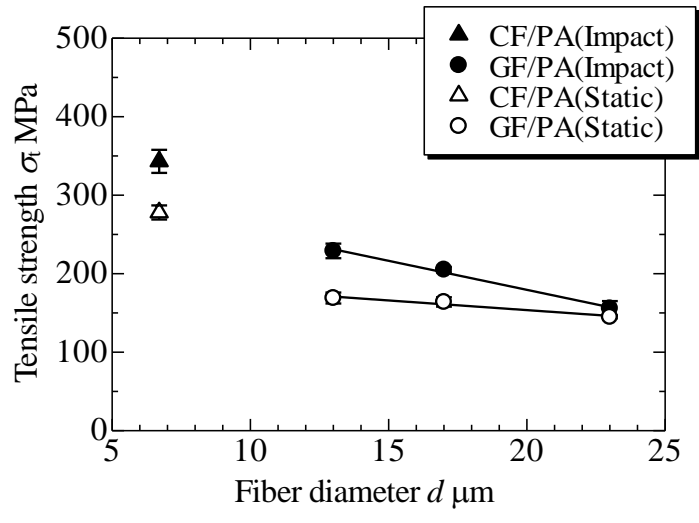

(b) LOA specimens

Fig. 12 Comparison of tensile strength between static and impact loading. The strain rates of impact tensile tests for GF/PA and $\mathrm{CF} / \mathrm{PA}$ are about $120 \mathrm{~s}^{-1}$ and $80 \mathrm{~s}^{-1}$, respectively. Values of the CF/PA are $V_{\mathrm{f}}=39.0 \%$ equivalent. The GF/PA with smaller fiber diameter shows more significant strain rate dependency on the tensile strength. In the HOA specimens, it is suggested that the GF/PA shows superior strain rate dependency on the tensile strength to the CF/PA. 
Table 4 Comparison of the increasing value and ratio of the tensile strength for the HOA specimens and PA. The strain rates of impact tensile tests for GF/PA, CF/PA and PA are about $120 \mathrm{~s}^{-1}, 80 \mathrm{~s}^{-1}, 100 \mathrm{~s}^{-1}$, respectively.

\begin{tabular}{c|c|c|c|c|c}
\hline \hline & GF13/PA & GF17/PA & GF23/PA & CF/PA & PA \\
\hline Increasing value of strength $I_{\mathrm{v}} \mathrm{MPa}$ & 121 & 106 & 79.2 & 51.1 & 22.3 \\
\hline Increasing ratio of strength $I_{\mathrm{r}} \%$ & 57.6 & 53.1 & 45.1 & 15.8 & 28.1 \\
\hline
\end{tabular}

Table 5 Comparison of the increasing value and ratio of the tensile strength for the LOA specimens. The strain rates of impact tensile tests for GF/PA and CF/PA are about $120 \mathrm{~s}^{-1}, 80 \mathrm{~s}^{-1}$, respectively.

\begin{tabular}{c|c|c|c|c}
\hline \hline & GF13/PA & GF17/PA & GF23/PA & CF/PA \\
\hline Increasing value of strength $I_{\mathrm{v}} \mathrm{MPa}$ & 59.6 & 41.3 & 11.1 & 65.5 \\
\hline Increasing ratio of strength $I_{\mathrm{r}} \%$ & 35.2 & 25.2 & 7.66 & 23.6 \\
\hline
\end{tabular}

静的負荷下，衝撃負荷下における引張強度と繊維径の関係を図 12 に示した. GF/PA，CF/PA の衝撃負荷下の強 度は, 取得したデータの中で, それぞれひずみ速度 $120 \mathrm{~s}^{-1}, 80 \mathrm{~s}^{-1}$ 付近のデータの平均值を示している. また, CF/PA は図 11 と同様にして $V_{\mathrm{f}}=39.0$ \%に換算した值を示している. 加えて，ひずみ速度の変化に伴う強度の増加 量と増加率を表 4, 表 5 に示した. 図 12 より, 静的, 衝撃負荷のいずれにおいても強化繊維の細線化により GF/PA の強度が向上する傾向が確認できる．細線化による強度の増加は静的負荷下と比較して衝撃負荷下において顕著 である．表 4, 表 5 より，ひずみ速度の変化に伴う強度の増加量および増加率は, GF/PA では配向度の高い試験 片，強化繊維径の小さい試験片においてより大きくなっている. CF/PA と PAの強度増加率を比較すると, PA の 強度増加率が大きい，これより，ひずみ速度の変化に伴う CF/PA の強度増加は母材樹脂のひずみ速度依存性によ るものであると考えられる. また，HOA specimens において，GF/PA と CF/PA を比較すると， GF/PA は同一繊維 径で CF/PA と同程度以上の衝撃強度を有することが期待される。これより，GF/PA が衝撃負荷下で優れた特性を 発現することが示唆された，一方，LOA specimens では，衝撃負荷下においても，GF/PA は CF/PA の強度を下回 ることが推察される.

\section{$4 \cdot 3$ 織維長調査結果}

繊維長測定によって得られた試験前の各供試体の䋊維長分布を図 13 に示す．図 13 より，繊維径が小さい供試

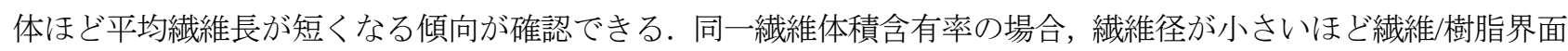
の総面積が大きくなり, 射出成形時の溶融粘度, 流動抵抗が大きくなる. その結果, 繊維径が小さい供試体では, 成形機のスクリュー回転により発生する樹脂の流れに対して繊維が配向しづらくなり，繊維破断が生じる(野村他， 2010)ため平均繊維長が短くなると考えられる.

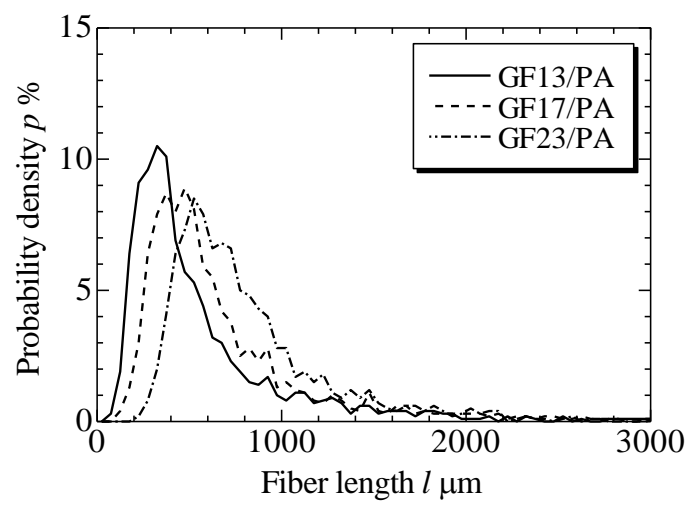

(a) HOA specimens

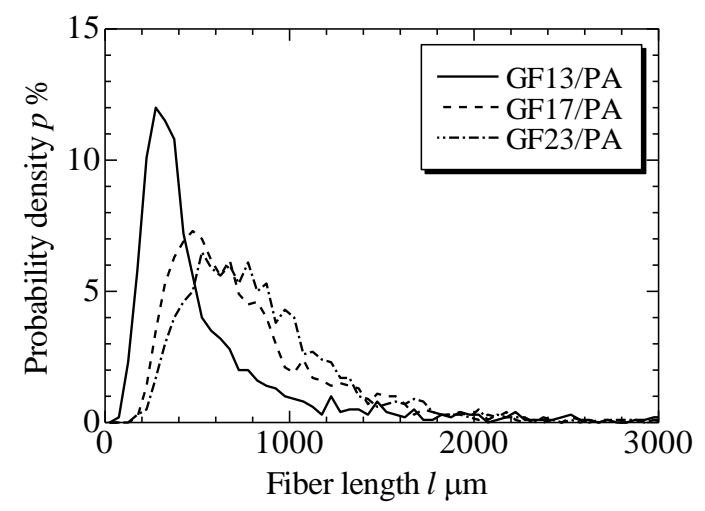

(b) LOA specimens

Fig. 13 Comparison of the fiber length distributions of injection molded plate. 
試験前後の平均繊維長を表 6 に示す，表 6 を見ると，静的，衝撃試験後は平均繊維長が減少していることが確 認できる。これより，引張試験において繊維破断が生じていることが確認できる.

Table 6 Comparison of average fiber length of specimens.

\begin{tabular}{c|c|c|c|c|c|c}
\hline \hline & \multicolumn{3}{|c|}{ HOA specimens } & \multicolumn{3}{c}{ LOA specimens } \\
\cline { 2 - 7 } & GF13/PA & GF17/PA & GF23/PA & GF13/PA & GF17/PA & GF23/PA \\
\hline Before test $l_{\mathrm{b}} \mu \mathrm{m}$ & 622 & 713 & 811 & 569 & 760 & 849 \\
\hline After static tensile test $l_{\mathrm{as}} \mu \mathrm{m}$ & 502 & 657 & 671 & - & - & - \\
\hline After impact tensile test $l_{\mathrm{ai}} \mu \mathrm{m}$ & 453 & 586 & 575 & - & - & - \\
\hline
\end{tabular}

\section{$4 \cdot 4$ 破断面観察結果}

破断面観察の結果得られた静的，衝撃引張試験後の破断面を図 14, 図 15 に示寸. 図 14, 図 15 より, 静的・衝 撃のいずれの試験結果も繊維の引抜けが主体の破壊となっていることが確認できる。これは，繊維径によらず同 様な結果であった。 また，繊維周辺の樹脂の様子に着目すると，静的負荷では樹脂が引き伸ばされた延性的な破 面を形成しているのに対し，衝撃負荷では脆性的な破面を示している。これより，母材樹脂の引張特性はひずみ 速度依存性を有していることが確認できる.

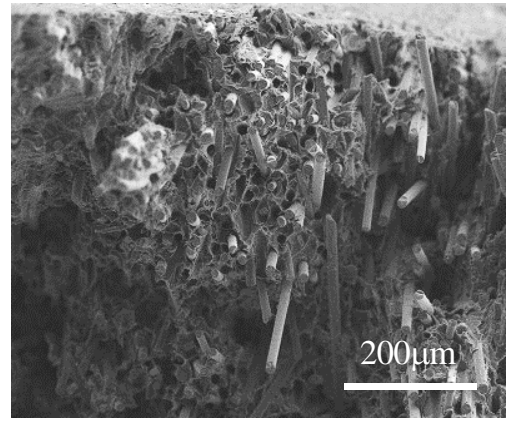

(a) GF13/PA

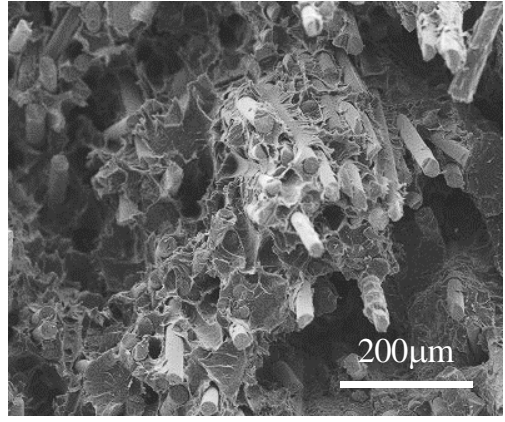

(b) GF23/PA

Fig. 14 SEM micrographs of the fracture surfaces of the HOA specimens after static tensile loading. Fiber pull-out is mainly observed. It suggests that the interfacial fracture between fiber and resin is occurred. The morphology do not depend on the fiber diameter.

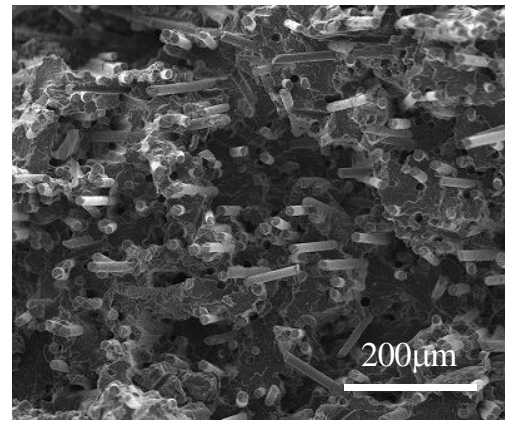

(a) GF13/PA

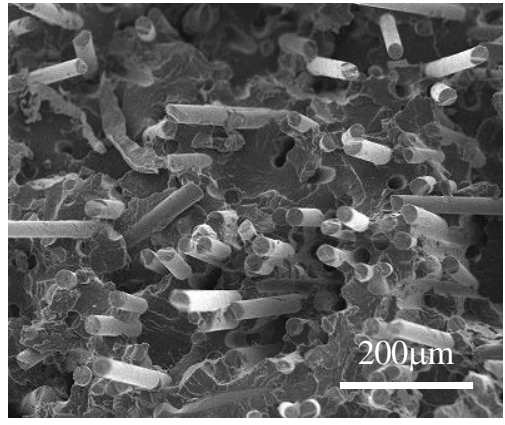

(b) GF23/PA

Fig. 15 SEM micrographs of the fracture surfaces of the HOA specimens after impact tensile loading. It suggests that the interfacial fracture between fiber and resin is also occurred under impact loading. In comparison to the surfaces under static loading, matrix shows brittle behavior. 


\section{5. 考 察}

\section{$5 \cdot 1$ 形態観察による繊維径の影響評価}

GF/PA の静的, 衝撃引張試験の結果, 強化繊維の細線化により引張強度およびそのひずみ速度依存性が向上す ることが確認された。そこで, 強化繊維の繊維径がガラス長繊維強化ポリアミドの衝撃引張特性に与える影響に ついて, 平均繊維長の変化および破壊形態の観点から考察を行った.

平均繊維長に関して, 表 6 に示した結果より引張負荷下では平均繊維長が減少しているすなわち繊維破断が生 じていることが確認された。.また，図 14, 図 15 に示した破断面観察の結果より, 繊維の引抜けすなわち繊維/樹 脂界面での破壊が生じていることが確認された。これらの結果より, 本研究で使用した試験片は, まず供試体中

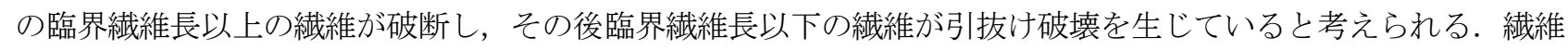
破断が生じていることから, 細線化により䋊維単体の強度およびそのひずみ速度依存性が向上したこと(谷口他, 2012)が FRP 全体の強度上昇に寄与した可能性がある．また，緎維/樹脂界面での破壊が生じていることから，強 化繊維の細線化に伴い, 繊維/樹脂界面の面積が増加することも引張強度に影響を与えていると考えられる(崔, 高 橋, 1991). GF23/PA の界面の面積で正規化した各供試体の界面の面積比 $A$ は, 繊維径を $d$ として以下の式で表せ る.

$$
A=\frac{d_{\mathrm{GF} 23}}{d}
$$

式（3）より, 纎維径 $17 \mu \mathrm{m}, 13 \mu \mathrm{m}$ の供試体では繊維径 $23 \mu \mathrm{m}$ の供試体と比較して, 繊維/樹脂界面の面積比がそ れぞれ 1.35 倍, 1.77 倍となる. したがって, 界面の面積の増加により, 界面に作用する平均せん断応力が減少し たこと, すなわち界面全体が負担することのできる荷重が増加したことが引張強度向上のメカニズムであると推 察される. 界面の面積の増加により, 界面剥離の進展に要するエネルギが増加したと考えられる. 式（3）におい て, 界面の面積比は繊維径の逆数に比例している. 図 12 を見ると, 繊維径の減少に伴って, GF/PAの静的, 衝撃 引張強度が増加している挙動が確認できる. この挙動からも, 式（3）で示された界面の面積は GF/PAの強度に 影響していると推察される.

また, 図 14, 図 15 に示した引抜け破壊では, 䋊維先端部が破壊の起点となる.これより, 細線化により繊維 端部の初期欠陥サイズが低減したことも, 剥離の発生を抑制するため, 引張強度の向上に寄与したと考えられる.

\section{$5 \cdot 2$ 強度予測モデルによる織維径の影響評価}

強化繊維の細線化に伴う GF/PA の強度向上の要因を特定すること, 衝撃負荷下におけるモデルの妥当性を評価 することを目的として, 強度予測モデルを用いて検討を行った。

短繊維強化複合材料の強度に関して, Kelly と Tyson は一本の不連続繊維とそれを取り囲む母材樹脂について 弾塑性解析を行い一方向短繊維強化複合材料の強度予測式を構築した(Kelly and Tyson, 1965). 実際の射出成形材 では強化䋊維の配向分布が存在することから, 福田らは Kelly-Tyson モデルを拡張し, 以下の強度算出式を提案し た(Fukuda and Chou, 1982).

$$
\sigma_{\mathrm{t}}=\eta_{0}\left\{\sum_{l_{i}<l_{\mathrm{c}}}\left(\frac{\sigma_{\mathrm{f}} V_{i} l_{i}}{2 l_{\mathrm{c}}}\right)+\sum_{l_{j}>l_{\mathrm{c}}}\left[\sigma_{\mathrm{f}} V_{j}\left(1-\frac{l_{\mathrm{c}}}{2 l_{j}}\right)\right]\right\}+\sigma_{\mathrm{m}}\left(1-V_{\mathrm{f}}\right)
$$

ここで， $\sigma_{\mathrm{t}}$ は複合材の引張強度， $\eta_{0}$ は繊維配向係数， $\sigma_{\mathrm{f}}$ は繊維強度， $\sigma_{\mathrm{m}}$ は母材の降伏応力， $l_{\mathrm{c}}$ は臨界繊維長， $l_{i}$ は

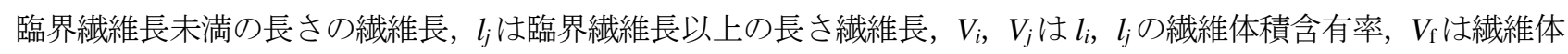
積含有率である．臨界纎維長 $l_{c}$ は次式のように表される.

$$
l_{\mathrm{c}}=\frac{\sigma_{\mathrm{f}} d}{2 \tau}
$$




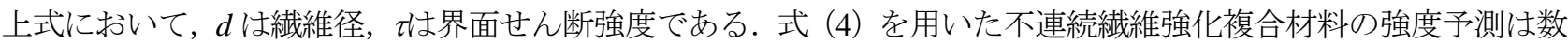
多く行われている(Arao et al., 2013, Mortazavian and Fatemi, 2015, Teixeira et al., 2013)．しかし，その多くは短纎維強 化複合材料の静的負荷下の強度を対象としたものである. 本研究では, 構成基材のひずみ速度依存性を考慮する ことにより，衝撃負荷下における長繊維強化ポリアミドの強度予測を試みた.

式（4）の予測式において使用した物性值を表 7 に示寸. GF17/PA の臨界繊維長は単繊維引抜き試験により得ら れた界面せん断強度から算出した. GF13/PA，GF23/PA の臨界繊維長は GF17/PA の臨界繊維長を基に，式（5）を 用いて算出した，今回は，界面せん断強度のひずみ速度依存性に関するデータが得られていないため，他の特性 に関するひずみ速度依存性と比較して小さいと仮定し, すべての速度域で静的負荷下のデータを使用した. また, 各供試体の繊維長は，図 13 に示した試験前の分布を用いた。

Table 7 Mechanical properties of materials used for prediction of tensile strength.

\begin{tabular}{c|c}
\hline \hline Fiber volume fraction $V_{\mathrm{f}} \%$ & 39.0 \\
\hline Tensile strength of glass fiber $\sigma_{\mathrm{f}} \mathrm{GPa}$ (Taniguchi et al., 2012) & $0.113 \ln \dot{\varepsilon}+3.01$ \\
\hline Tensile strength of polyamide $66 \sigma_{\mathrm{m}} \mathrm{MPa}$ & $1.54 \ln \dot{\varepsilon}+92.2$ \\
\hline Interfacial shear strength $\left(\dot{\varepsilon}=1.0 \times 10^{-4}\right) \tau \mathrm{MPa}$ & 24.0 \\
\hline
\end{tabular}

以上の条件のもとで強度予測を行い, 䋊維配向係数を変数として GF17/PA 試験結果にフィッティングを行っ た. 得られた $\eta_{0}$ を表 8 に, 予測結果を実験值と共に図 16 に示す.

Table 8 Fiber orientation factors of the HOA and LOA specimens.

\begin{tabular}{c|c|c}
\hline \hline & HOA specimens & LOA specimens \\
\hline Fiber orientation factor $\eta_{0}$ & 0.44 & 0.26 \\
\hline
\end{tabular}

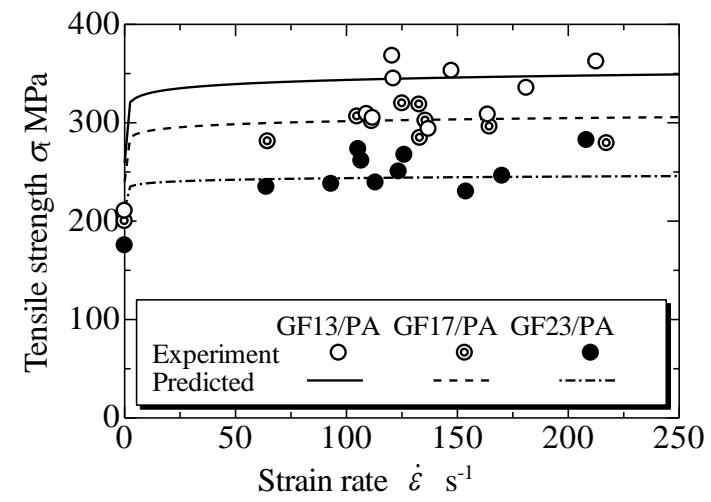

(a) HOA specimens

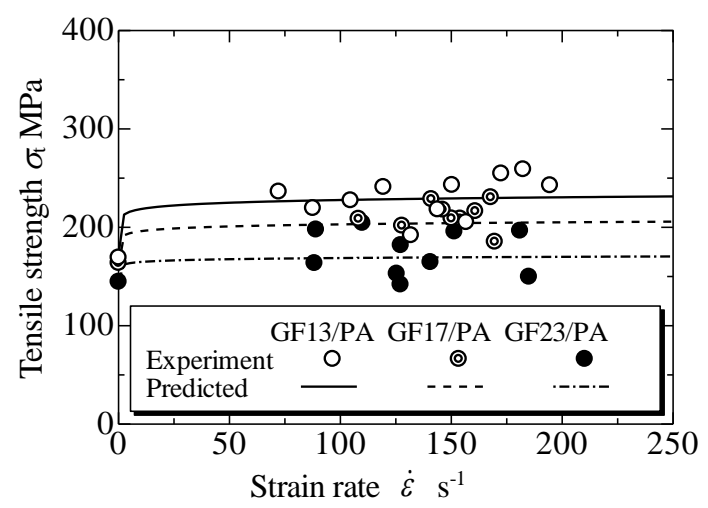

(b) LOA specimens

Fig. 16 Comparison of the experimental and the predicted results for strain rate dependency on the tensile strength of the HOA and LOA specimens. The predictions are found to be good agreement with the experimental results. It suggests that the main reason the impact tensile strength are higher for the smaller diameter samples is that the critical fiber length is decreased.

図 16 を見ると，試験結果と予測結果は良い一致を示していることがわかる.これより，構成基材のひずみ速度 依存性を考慮することで, 衝撃負荷下においても式 (4) が成立することが確認された. また，ある一つの繊維径 を有する供試体について繊維配向分布係数を決定することにより，あらゆる繊維径の供試体の強度を予測するこ とが可能であることが示唆された．本強度予測においては，表７に示すように，ガラス繊維の強度は繊維径によ らず同一とした．繊維強度が䋊維径に依存しないと仮定したうえで予測が良い一致を示したことから，樹脂中で は繊維径によるガラス繊維の強度の差は, 繊維単体の引張試験結果と比較して低減することが示唆された. これ 
は，ガラス繊維の表面の欠陥が樹脂により埋められたためと考えられる(Iba et al., 2002). なお，表 7 に示したガラ ス繊維の強度は谷口ら(谷口他, 2012)によって測定された值の中で最も高い強度を示した $d=3.2 \mu \mathrm{m}$ の結果を使用 している．これは，ガラス繊維単体の強度が細線化に伴い一定值に漸近する傾向を示しており，この值が樹脂中 でのガラス繊維の強度であると仮定したためである.強度予測結果より, 強化繊維の細線化に伴う強度の増加は, 主に式 (5) で示された臨界纎維長の減少によるものであると推察される.すなおわち, 細線化による臨界繊維長の 減少により，射出成形材中で荷重を十分に負担寸る繊維の割合が増加したことが強度の向上につながったと考え られる，本研究では，界面せん断強度のひずみ速度依存性は小さいと仮定したが，界面せん断強度には少なから ず速度依存性が存在すると考えられる. そのため, 本特性の取得が必要であると考えられる. また, 本研究では, 䋊維径に依らず界面せん断強度は一定とした，今後，各繊維径の単繊維引抜き試験を行うことで，繊維端の欠陥 サイズの影響を含んだ界面せん断強度の取得，それを用いた強度の予測が可能であると考えられる.

\section{6. 結 言}

本研究では, 平均繊維径 $13 \mu \mathrm{m}, 17 \mu \mathrm{m}, 23 \mu \mathrm{m}$ のガラス繊維を強化材とする射出成形繊維強化ポリアミドの衝 撃引張試験を行うことにより, 強化䋊維の䋊維径が与える影響を評価した。 得られた知見を以下に示す.

（1）繊維配向角を統一した試験片に対して, 静的引張試験, 衝撃引張試験を行った結果, GF/PA では強化繊維の 繊維径が小さいほど高い強度，顕著なひずみ速度依存性を示すことが確認された．繊維径，繊維配向角を制 御することにより，射出成形材においても高い衝撃強度が得られることが実験的に示された.

（2）GF/PA は CF/PA と比較して強度に関するひずみ速度依存性が大きいことが確認された。この傾向は, 配向 度の低い試験片と比較して配向度の高い試験片において顕著であった．衝撃強度を基準として選定される 部材においては CF/PA を GF/PA で代替できる可能性が示された。

（3）繊維長調査，破断面観察を行った結果，いずれの供試体も繊維破断，繊維/樹脂界面での破壊が主体である ことが確認された.

（4）GF/PAの強度予測を行った結果，実験結果とよい一致を示した。これより，ある一種類の繊維径を有する供 試体について繊維配向分布係数を決定することにより，あらゆる繊維径の供試体の強度予測が可能である ことが示唆された.

（5）強化繊維の細線化に伴う引張強度の増加は, 䋊維/樹脂界面の面積比の増加に伴い, 界面全体が負担できる 荷重が増加したこと, 臨界繊維長の減少に伴い, 荷重を十分に負担する繊維の割合が増加したことが要因で あると推察された.

\section{文献}

Arao, Y., Yumitori, S., Suzuki, H., Tanaka, T., Tanaka, K. and Katayama, T., Mechanical properties of injection-molded carbon fiber/polypropylene composites hybridized with nanofillers, Composites: Part A, Vol.55 (2013), pp.19-26.

Bernasconi, A., Davoli, P., Basile, A. and Filippi, A., Effect of fiber orientation on the fatigue behavior of a short glass fiber reinforced polyamide-6, International Journal of Fatigue, Vol.29 (2007), pp.199-208.

崔洛三, 高橋清, 短繊維強化ポリエチレンテレフタレートの微視構造ならびに破壞機構に対する繊維径の効果, 日本複合材料学会誌, Vol.17, No.5 (1991), pp.205-212.

De Monte, M., Moosbrugger, E. and Quaresimin, M., Influence of temperature and thickness on the off-axis behavior of short glass fiber reinforced polyamide 6.6 - Quasi-static loading, Composites: Part A, Vol.41 (2010), pp.859-871.

Fukuda, H. and Chou, T., A probability theory of the strength of short-fibre composites with variable fibre length and orientation, Journal of Materials Science, Vol.17 (1982), pp.1003-1011.

Fu, X., He, B. and Chen, X., Effects of compatibilizers on mechanical properties of long glass fiber-reinforced polypropylene, Journal of Reinforced Plastics and Composites, Vol.29, No.6 (2010), pp.936-949.

Hattum, F. V. and Breugel, S. V., LFT: the future of reinforced thermoplastics?, Reinforced Plastics, Vol.45, No.6 (2001), pp.4244.

Iba, H., Chang, T. and Kagawa, Y., Optically transparent continuous glass fibre-reinforced epoxy matrix composite: fabrication, 
optical and mechanical properties, Composites Science and Technology, Vol.62 (2002), pp.2043-2052.

Kelly, A. and Tyson, W. R., Tensile properties of fiber-reinforced materials: Copper/tungsten and copper/molybdenum, Journal of the Mechanics and Physics of Solids, Vol.13 (1965), pp.329-350.

金太成, 荒尾与史彦, 谷口憲彦, 西脇剛史, 平山紀夫, 細井厚志, 川田宏之, 射出成形ガラス長繊維強化熱可塑性 プラスチックの衝撃特性，日本複合材料学会 JCCM-6, CD-ROM 論文集 (2015), 1A-15.

Mortazavian, S. and Fatemi, A., Effects of fiber orientation and anisotropy on tensile strength and elastic modulus of short fiber reinforced polymer composites, Composites: Part B, Vol.72 (2015), pp.116-129.

Naik, N. K., Yernamma, P., Thoram, N. M., Gadipatri, R. and Kavala, V. R., High strain rate tensile behavior of woven fabric E-glass/epoxy composite, Polymer Testing, Vol.29 (2010), pp.14-22.

西田政弘, 加藤英則, 植物由来エンプラ・ポリアミド 11 の衝撃特性の評価, 日本機械学会論文集 A 編, Vol.77, No.777 (2011), pp.789-793.

野村学, 菅野進, 山尾忍, GF 強化熱可塑性樹脂の特性に及ぼす繊維断面形状の影響, 日本複合材料学会誌, Vol.36, No.6 (2010), pp.230-236.

Ochola, R. O., Marcus, K., Nurick, G. N. and Franz, T., Mechanical behaviour of glass and carbon fibre reinforced composites at varying strain rates, Composites Structures, Vol.63 (2004), pp.455-467.

小澤憲人, 金太成, 荒尾与史彦, 谷口憲彦, 西脇剛史, 平山紀夫, 中村幸一, 川田宏之, ガラス短繊維強化ポリアミ ドの衝撃特性に及ぼす繊維径および䋊維断面形状の影響, 日本機械学会 M\&M2014 材料力学カンファレンス CD-ROM 論文集 (2014), OS1716.

Ramsteiner, F. and Theysohn, R., The influence of fiber diameter on the tensile behavior of short-glass-fiber reinforced polymers, Composites Science and Technology, Vol.24 (1985), pp.231-240.

Stewart, R., Rebounding automotive industry welcome news for FRP, Reinforced Plastics, Vol.55, No.1 (2011a), pp.38-44.

Stewart, R., Thermoplastic composites - recyclable and fast to process, Reinforced Plastic, Vol.55, No.3 (2011b), pp.22-28.

田中和人, 正部祐季, 片山傳生，単䋊維引抜き試験による炭素繊維/ポリアミド樹脂界面の破壊特性評価，材料， Vol.58, No.7 (2009), pp.635-641.

谷口憲彦, 荒尾与史彦, 西脇剛史, 平山紀夫, 中村幸一, 川田宏之, ガラス繊維の衝撃引張り特性に関する実験的 検討, 日本複合材料学会誌, Vol.38, No.4 (2012), pp.137-143.

Taniguchi, N., Nishiwaki, T., Hirayama, N., Nishida, H. and Kawada, H., Dynamic tensile properties of carbon fiber composite based on thermoplastic epoxy resin loaded in matrix-dominant directions, Composites Science and Technology, Vol.69 (2009), pp.207-213.

谷口憲彦, 西脇剛史, 平山紀夫, 西田裕文, 川田宏之, 熱可塑性エポキシ樹脂をマトリクスとする一方向繊維強化 複合材料の衝撃引張り特性評価, 日本機械学会論文集 A 編, Vol.75, No.758 (2009), pp.1284-1289.

Teixeira, D., Giovanela, M., Gonella, L. B. and Crespo, J. S., Influence of flow restriction on the microstructure and mechanical properties of long glass fiber-reinforced polyamide 6.6 composites for automotive applications, Materials and Design, Vol.47 (2013), pp.287-294.

Thomason, J. L., The influence of fiber length and concentration on the properties of glass fiber reinforced polypropylene. 6. The properties of injection molded long fiber PP at high fiber content, Composites: Part A, Vol.36 (2005), pp.995-1003.

Thomason, J. L., The influence of fiber length, diameter and concentration on the impact performance of long glass-fiber reinforced polyamide 6,6, Composites: Part A, Vol.40 (2009), pp.114-124.

Thomason, J. L., The influence of fiber length, diameter and concentration on the strength and strain to failure of glass fiberreinforced polyamide 6,6, Composites: Part A, Vol.39 (2008), pp.1618-1624.

横山隆, 中井賢治, 稲垣智也, 一方向強化カーボン/エポキシ積層複合材の衝撃圧縮破壊挙動：直交異方性材料の 主軸 3 方向における特性, 材料, Vol.58, No.11 (2009), pp.887-894.

Zhou, Y. and Mallick, P. K., A non-linear damage model for the tensile behavior of an injection molded short E-glass fiber reinforced polyamide-6,6, Materials Science and Engineering A, Vol.393 (2005), pp.303-309.

\section{References}

Arao, Y., Yumitori, S., Suzuki, H., Tanaka, T., Tanaka, K. and Katayama, T., Mechanical properties of injection-molded carbon fiber/polypropylene composites hybridized with nanofillers, Composites: Part A, Vol.55 (2013), pp.19-26.

Bernasconi, A., Davoli, P., Basile, A. and Filippi, A., Effect of fiber orientation on the fatigue behavior of a short glass fiber reinforced polyamide-6, International Journal of Fatigue, Vol.29 (2007), pp.199-208. 
Choi, N. S. and Takahashi, K., Influence of fiber diameter on microstructure and failure mechanisms of short fiber reinforced poly (ethylene terephthalate), Transaction of the Japan Society for Composite Materials, Vol.17, No.5 (1991), pp.205-212 (in Japanese).

De Monte, M., Moosbrugger, E. and Quaresimin, M., Influence of temperature and thickness on the off-axis behavior of short glass fiber reinforced polyamide 6.6 - Quasi-static loading, Composites: Part A, Vol.41 (2010), pp.859-871.

Fukuda, H. and Chou, T., A probability theory of the strength of short-fibre composites with variable fibre length and orientation, Journal of Materials Science, Vol.17 (1982), pp.1003-1011.

Fu, X., He, B. and Chen, X., Effects of compatibilizers on mechanical properties of long glass fiber-reinforced polypropylene, Journal of Reinforced Plastics and Composites, Vol.29, No.6 (2010), pp.936-949.

Hattum, F. V. and Breugel, S. V., LFT: the future of reinforced thermoplastics?, Reinforced Plastics, Vol.45, No.6 (2001), pp.4244.

Iba, H., Chang, T. and Kagawa, Y., Optically transparent continuous glass fibre-reinforced epoxy matrix composite: fabrication, optical and mechanical properties, Composites Science and Technology, Vol.62 (2002), pp.2043-2052.

Kelly, A. and Tyson, W. R., Tensile properties of fiber-reinforced materials: Copper/tungsten and copper/molybdenum, Journal of the Mechanics and Physics of Solids, Vol.13 (1965), pp.329-350.

Kim, T., Arao, Y., Taniguchi, N., Nishiwaki, T., Hirayama, N., Hosoi, A. and Kawada, H., Impact properties of injection molded long fiber reinforced thermoplastics, Proceedings of the JSCM JCCM-6 (2015), 1A-15 (in Japanese).

Mortazavian, S. and Fatemi, A., Effects of fiber orientation and anisotropy on tensile strength and elastic modulus of short fiber reinforced polymer composites, Composites: Part B, Vol.72 (2015), pp.116-129.

Naik, N. K., Yernamma, P., Thoram, N. M., Gadipatri, R. and Kavala, V. R., High strain rate tensile behavior of woven fabric E-glass/epoxy composite, Polymer Testing, Vol.29 (2010), pp.14-22.

Nishida, M. and Kato, H., Evaluation of impact properties of plant-derived engineering plastic polyamide11, Transactions of the Japan Society of Mechanical Engineers, Series A, Vol.77, No.777 (2011), pp.789-793 (in Japanese).

Nomura, M., Kanno, S. and Yamao, S., Influence of shape of cross section on properties of GF reinforced thermo-plastics, Transaction of the Japan Society for Composite Materials, Vol.36, No.6 (2010), pp.230-236 (in Japanese).

Ochola, R. O., Marcus, K., Nurick, G. N. and Franz, T., Mechanical behaviour of glass and carbon fibre reinforced composites at varying strain rates, Composites Structures, Vol.63 (2004), pp.455-467.

Ozawa, K., Kim, T., Arao, Y., Taniguchi, N., Nishiwaki, T., Hirayama, N., Nakamura, K. and Kawada, H., Influence of fiber diameter and cross sectional shape on the impact properties of short glass fiber reinforced polyamide, Proceedings of the JSME M\&M2014 Material Mechanics Conference (2014), OS1716 (in Japanese).

Ramsteiner, F. and Theysohn, R., The influence of fiber diameter on the tensile behavior of short-glass-fiber reinforced polymers, Composites Science and Technology, Vol.24 (1985), pp.231-240.

Stewart, R., Rebounding automotive industry welcome news for FRP, Reinforced Plastics, Vol.55, No.1 (2011a), pp.38-44.

Stewart, R., Thermoplastic composites - recyclable and fast to process, Reinforced Plastic, Vol.55, No.3 (2011b), pp.22-28.

Tanaka, K., Masabe, Y. and Katayama, T., Evaluation of interfacial properties for carbon fiber/polyamide model composites by means of single fiber pull-out test, Journal of the Society of Materials Science, Vol.58, No.7 (2009), pp.635-641 (in Japanese).

Taniguchi, N., Arao, Y., Nishiwaki, T., Hirayama, N., Nakamura, K. and Kawada, H., Experimental study on impact tensile property of glass fiber, Transaction of the Japan Society for Composite Materials, Vol.38, No.4 (2012), pp.137-143 (in Japanese).

Taniguchi, N., Nishiwaki, T., Hirayama, N., Nishida, H. and Kawada, H., Dynamic tensile properties of carbon fiber composite based on thermoplastic epoxy resin loaded in matrix-dominant directions, Composites Science and Technology, Vol.69 (2009), pp.207-213.

Taniguchi, N., Nishiwaki, T., Hirayama, N., Nishida, H. and Kawada, H., Evaluating the impact tensile properties of unidirectional fibre-reinforced composites with thermoplastic epoxy resin, Transactions of the Japan Society of Mechanical Engineers, Series A, Vol.75, No.758 (2009), pp.1284-1289 (in Japanese).

Teixeira, D., Giovanela, M., Gonella, L. B. and Crespo, J. S., Influence of flow restriction on the microstructure and mechanical properties of long glass fiber-reinforced polyamide 6.6 composites for automotive applications, Materials and Design, Vol.47 (2013), pp.287-294.

Thomason, J. L., The influence of fiber length and concentration on the properties of glass fiber reinforced polypropylene. 6. The properties of injection molded long fiber PP at high fiber content, Composites: Part A, Vol.36 (2005), pp.995-1003. 
Thomason, J. L., The influence of fiber length, diameter and concentration on the impact performance of long glass-fiber reinforced polyamide 6,6, Composites: Part A, Vol.40 (2009), pp.114-124.

Thomason, J. L., The influence of fiber length, diameter and concentration on the strength and strain to failure of glass fiberreinforced polyamide 6,6, Composites: Part A, Vol.39 (2008), pp.1618-1624.

Yokoyama, T., Nakai, K. and Inagaki, T., Impact compressive failure of a unidirectional carbon/epoxy laminated composite in three principal material axes, Journal of the Society of Materials Science, Vol.58, No.11 (2009), pp.887-894 (in Japanese).

Zhou, Y. and Mallick, P. K., A non-linear damage model for the tensile behavior of an injection molded short E-glass fiber reinforced polyamide-6,6, Materials Science and Engineering A, Vol.393 (2005), pp.303-309. 